Original Article

\title{
Euphlyctis Cyanophlyctis Schneider, 1799 (Amphibia: Dicroglossidae) in district Lower Dir, Pakistan
}

\author{
Euphlyctis Cyanophlyctis (Schneider, 1799) Amphibia: Dicroglossidae no distrito de \\ Lower Dir, Paquistão
}

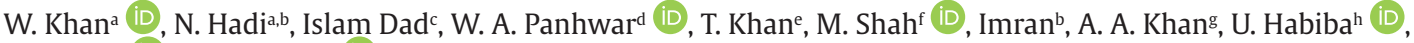 \\ G. Khaliqi iD and A. Alamb (iD \\ aUniversity of Malakand, Department of Zoology, Lower Dir, Khyber Pakhtukhwa, Pakistan \\ 'Hazara University Mansehra, Department of Zoology, Mansehra, Pakistan \\ 'University of Karachi, Department of Zoology, Karachi, Pakistan \\ dUniversity Khairpur Miris Sindh, Department of Zoology Shah Abdul Latif, Khairpur, Pakistan \\ eVirtual University of Lahore, Department of Molecular Biology, Lahore, Pakistan \\ fUniversity of Swat, Centre for Animal Sciences \& Fisheries, Swat, Pakistan \\ ${ }^{g}$ Abdul Wali Khan University Mardan, Mardan, Pakistan \\ hUniversity of Haripur, Department of Forestry and Wildlife Management, Haripur, Pakistan \\ iLasbela University of Agriculture Water and Marine Sciences, Department of Horticulture, Faculty of Agriculture, Uthal, Balochistan
}

\begin{abstract}
Euphlyctis cyanophlyctis (the skittering frog) is one of the most widespread species in Pakistan. Present study was aimed to know the presence of Euphlyctis cyanophlyctis in urban and rural areas of Lower Dir, the North-western Pakistan. A total of 33 frogs were collected, including 15 from rural and 18 from urban areas. The frogs were caught by hands covered with gloves instead of using nets. The collection was managed from August to October 2016 and from April to May 2018. Morphometric analysis, coloration as well as photographs of the frogs have been provided in detail. Skittering frogs were seen frequent in swampy areas near the water bodies. These frogs were mostly seen after sunset.
\end{abstract}

Keywords: morphological variation, morphometric analysis, E. cyanophlyctis, water bodies, dicroglossid frogs.

\section{Resumo}

Euphlyctis cyanophlyctis (a rã que desliza) é uma das espécies mais comuns no Paquistão. O presente estudo teve como objetivo conhecer a presença de Euphlyctis cyanophlyctis em áreas urbanas e rurais de Lower Dir, noroeste do Paquistão. Um total de 33 sapos foram coletados, incluindo 15 de áreas rurais e 18 de áreas urbanas. As rãs foram apanhadas com as mãos cobertas com luvas em vez de redes. A coleta foi gerenciada de agosto a outubro de 2016 e de abril a maio de 2018. Análises morfométricas, coloração e também fotografias das rãs foram fornecidas em detalhes. Rãs saltitantes foram vistas freqüentemente em áreas pantanosas próximas aos corpos d'água. Essas rãs eram vistas principalmente após o pôr do sol.

Palavras-chave: variação morfológica, análise morfométrica, E. cyanophlyctis, corpos d'água, rãs dicroglossídeos.

\section{Introduction}

Pakistan is generally an amphibian-poor country because of its prevailing arid environmental conditions. However, with the humid riparian conditions in the Indus Valley, torrents and streams in the northern Himalayan sub-mountainous region, and the subterranean water channels in the western Balochistan highland, there are 25 amphibian species known from Pakistan (Khan, 2006). These species fall in twelve genera of four major families' viz., Bufonidae, Megophryidae,

Microhylidae and Dicroglossidae. The dicroglossid frogs are represented by seven genera: Allopaa, Chrysopaa, Euphlyctis, Fejervarya, Hoplobatrachus, Nanorana and Sphaerotheca (Khan, 2010).

Euphlyctis cyanophlyctis (Schneider, 1799) is one of the most widespread frog in southern Asia. This species has been assigned to various genera over the time, including Rana (Rana cyanophlyctis Boulenger, 1920), Bufo (Bufo cyanophlyctis Latreille, 1801) and Dicroglossus 
(Dicroglossus cyanophlyctis Deckert, 1938) and it has been revised by its current name by Dubois (1975). The type locality of this species is probably Tranquebar in southeastern India (Bauer, 1998) and the species is believed to be distributed throughout southern Asia from southeastern Iran to Vietnam and Sri Lanka (Frost, 2013).

Euphlyctis cyanophlyctis is a common species and it remains active almost throughout the year, whereas other species are active only during summer, from March to September. Solitary Euphlyctis cyanophlyctis individuals make calls from permanent water bodies almost all over the year, although actual breeding activity is initiated in early summer when water temperature rises to $10-15^{\prime} \mathrm{C}$ (Chowdhury et al., 2016).

The distribution and taxonomy of E. cyanophlyctis have been debated by several authors. Boulenger (1920) mentioned that Blanford recorded it from Makran, Persian Baluchistan. Earlier, Nikolskii (1899) described Rana cyanophlyctis seistanica from Sistan, Iran based on its smaller tympanum and longer snout. This subspecies has only been reported from the type locality and along the border of Iran, Pakistan, Afghanistan (Khan, 2004). Anderson (1963) later recorded Rana cyanophlyctis from Iran. Baluch and Kami (1995) reported Rana cyanophlyctis cyanophlyctis from southern and southeastern Iran and proposed $R$. cyanophlyctis seistanica to be a synonym. Moreover, Khan (1997) described a new subspecies, E. cyanophlyctis microspinulata from Khuzdar, Baluchestan, Pakistan. In present study we address the distribution and biometric analysis of E.cyanophylectis in district Lower Dir, Pakistan.

\section{Materials and Methods}

\subsection{Study area}

District, Lower Dir, lies at Khyber Pakhtunkhwa, Pakistan. Its boundaries are linked with Chitral in North, in South with district Malakand and in the East with district Swat, while in West, it joins Afghanistan. Total reported area of the district is $1585 \mathrm{~km}^{2}$ reported with 717649 populations approximately. The climate is dry with hot summer and cold winter. The annual rainfall varies between $600 \mathrm{~mm}$ to $1100 \mathrm{~mm}$. The annual average minimum and maximum temperature ranges from $12^{\circ} \mathrm{C}$ and $29^{\circ} \mathrm{C}$, respectively. Agriculture is the main occupation followed by live stock for the livelihood of inhabitants (Khan et al., 2018) (Figure 1).

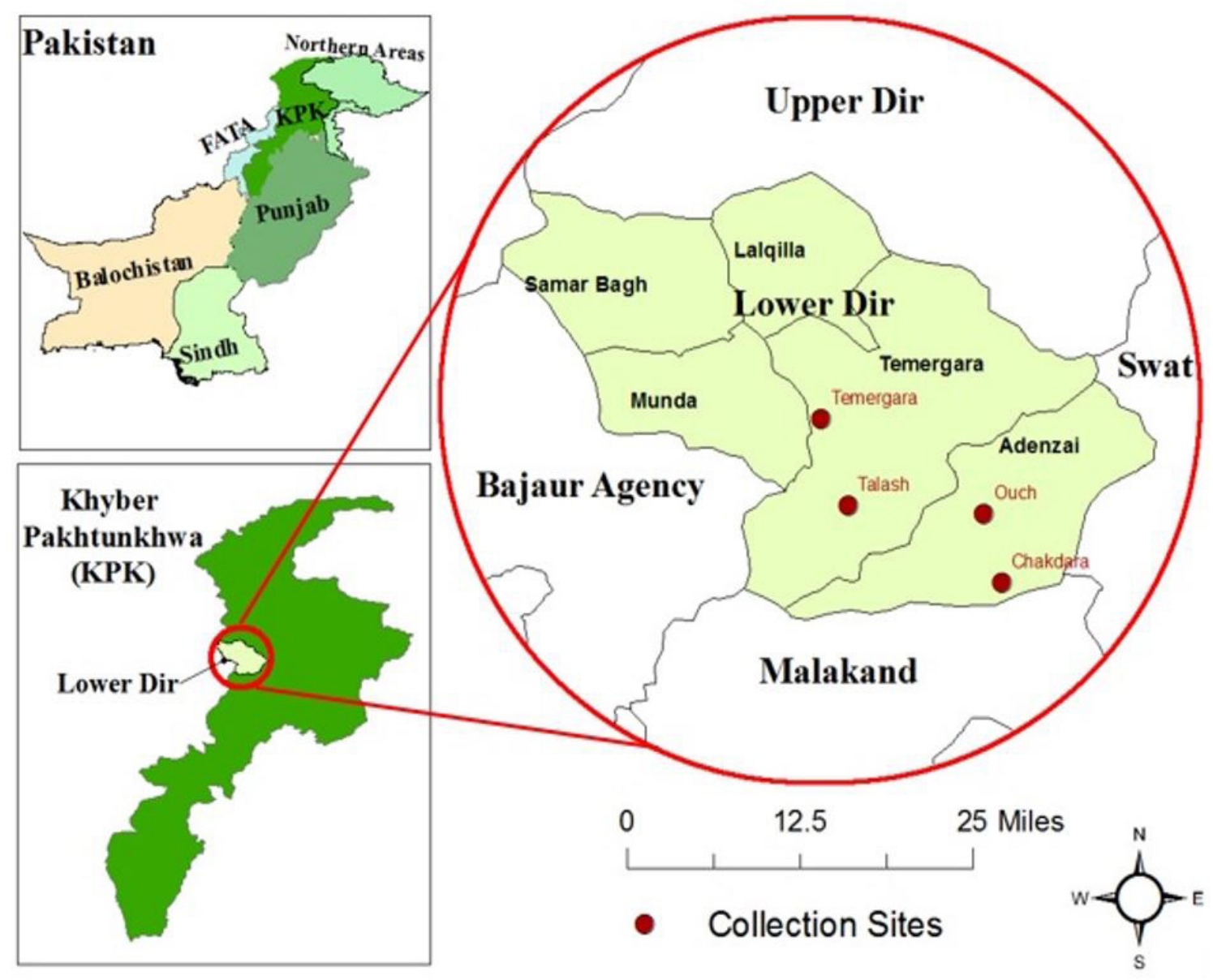

Figure 1. Left upper is map of Pakistan, Left lower is the Khyber Pakhtumkhwa province and the encircle represents the lower Dir district in which the red spots are showing collection sites. 


\subsection{Sample collection}

Frogs were collected during the months of August to October 2016 and from April to May 2018 from the urban and rural settlements of district, Lower Dir, Khyber Pakhtunkhwa, Pakistan. Each of the frog specimens were collected at night with hands covered with gloves instead of using nets. With the help of using torch lights frogs were caught from their localities. Captured frogs were kept alive in disposable bottles having holes in them for the passing of fresh air for breathing. After collection the frogs were carried to the Laboratory of Parasitology, Department of Zoology, University of Malakand, for further study.

\subsection{Anesthesia and laboratory analysis}

The fogs were euthanized with chloroform. The containers containing the frogs were first given a serial number and then each of the frog specimens were placed in a separate petri dish to observe external body surface for the presence of ectoparasite (if any). Skin as well as color of the frog were observed for external abnormalities. Dead specimens of the frogs and their carcasses were weighted with the help of a digital balance. Morphometric analysis (Snout Vent Length, Tibial length, head length, head breadth, internarial space, inter-orbital space, upper eyelid length, upper eyelid breadth, snout length, snout to nares length, naris to eye length, length of arm, length of hand, length of leg, length of foot, length of tarsal, length of inner metatarsal and length of tubercle) were measured with the help of vernire calipers in millimeter. These frogs were measured and sexed to assess the biometric analysis. The specimens were identified by using the keys provided by Khan (2017).

\section{Results}

The morphometric analysis of Euphlyctis cyanophlyctis was shown in Table 1. These specimens were characterized as: head longer than broad, upper jaw protruding, canthus indistinct, loreal oblique, snout longer than upper eyelid, naries dorsal, cresecentric, transversely enlarged, nearer to snout than eye, rim raised from snout surface and posteriorly produced in to a distinct brown tipped post narial papilla, dorsum is smooth with longitudinally enlarged tubercles interspersed with minute spinules, tubercles More concentrated on convex and lower half of tibia, spinules borne on small tubercles, fingers and

Table 1. Variations in various characteristics of specimens of E.cyanophlyctis $(\mathrm{n}=33)$ in Lower Dir, Pakistan.

\begin{tabular}{|c|c|c|c|c|c|c|c|c|c|c|}
\hline \multirow{2}{*}{ Character } & \multicolumn{2}{|c|}{$\begin{array}{c}\text { E.c.microspinulata } \\
\text { subspp nov }\end{array}$} & \multicolumn{2}{|c|}{$\begin{array}{c}\text { E.c.ehrenbergii } \\
\text { (Boulenger, 1920) }\end{array}$} & \multicolumn{2}{|c|}{ E.c. cynophlyctis } & \multicolumn{2}{|c|}{$\begin{array}{l}\text { Rural (present } \\
\text { collection) }\end{array}$} & \multicolumn{2}{|c|}{$\begin{array}{l}\text { Urban (present } \\
\text { collection) }\end{array}$} \\
\hline & Male & Female & Male & Female & Male & Female & $\begin{array}{c}\text { Male } \\
(n=10)\end{array}$ & $\begin{array}{c}\text { Female } \\
(n=8)\end{array}$ & $\begin{array}{l}\text { Male } \\
(n=5)\end{array}$ & $\begin{array}{c}\text { Female } \\
(n=10)\end{array}$ \\
\hline Snout Vent length & $41-45$ & $50-63$ & $60-66$ & $75-92$ & $40-47$ & $45-62$ & $38-42$ & $50-60$ & $40-43$ & $51-62$ \\
\hline Tibial length & $21-24$ & $25-30$ & $29-30$ & $39-41$ & $21-24$ & 24-31 & $20-22$ & $23-30$ & $21-22$ & $24-31$ \\
\hline \multicolumn{11}{|l|}{ Head: } \\
\hline Length & $15-17$ & $17-23$ & $21-21.5$ & $23-24$ & 14-15 & $15-21$ & $12-17$ & $18-23$ & $14-18$ & $19-23$ \\
\hline Breadth & $15-18$ & $16-23$ & $22-23$ & 26.27 & $15-16$ & $17-23$ & $13-16$ & $16-21$ & $16-17$ & $16-22$ \\
\hline \multicolumn{11}{|l|}{ Space: } \\
\hline Internarial & $1.7-2$ & $2-3$ & $2-2.4$ & $2-3$ & $1-1.5$ & $2-2.6$ & $1-2$ & $2-2.5$ & $1-2$ & $2-3$ \\
\hline Inter-orbital & $1-3$ & $2-3$ & $2-3$ & $3-3.8$ & $2-3$ & $2-3$ & $1-2$ & $2-2.5$ & $1-2$ & $2-3$ \\
\hline \multicolumn{11}{|l|}{ Upper eyelid } \\
\hline Length & $5-6$ & $5-7$ & $6-6.5$ & 6.6 .5 & 5.6 & 5.6 & $4-5$ & $5-7$ & $5-6$ & $6-7$ \\
\hline Breadth & $2-4$ & $3-4$ & 4.4 .2 & 4.4 .2 & 3.4 & $3-5.4$ & $2-3$ & $3-4$ & $2-3.5$ & $3-4$ \\
\hline \multicolumn{11}{|l|}{ Snout length } \\
\hline Snout to naris & $2-4$ & $3-6$ & $3-4.4$ & 3.1 & $3-4$ & $3-6$ & $2-4$ & $3-4.5$ & $2-4$ & $3-5.5$ \\
\hline Naris to eye & 3 & $3-5$ & 4 & $5-6$ & $3-5.4$ & 5.6 & $3-4$ & $3-4$ & $3-4$ & $3-5$ \\
\hline \multicolumn{11}{|l|}{ Length of } \\
\hline Arm & $23-24$ & $27-33$ & $29-33$ & $36-39$ & $22-24$ & $26-34$ & $20-22$ & $25-30$ & $21-23$ & $26-33$ \\
\hline hand & $10-12$ & $12-14$ & $14-16$ & 18.18 & $10-12$ & $13-14$ & $10-12$ & $11-13$ & $10-12$ & $11-13.5$ \\
\hline Leg & $62-71$ & $69-90$ & $82-82$ & 91-103 & $61-72$ & 69-91 & $58-69$ & $68-88$ & $60-70$ & $70-90$ \\
\hline Foot & $21-26$ & $23-30$ & $27-30$ & 34-35 & $21-25$ & 23-31 & $20-25$ & $21-29$ & $20-26$ & $22-31$ \\
\hline Tarsal & $31-34$ & $27-38$ & $14-15$ & 18.7 & $31-34$ & $26-38$ & $29-32$ & $27-30$ & $29-33$ & $28-30$ \\
\hline Tubercle & $2-3$ & $3-4$ & $2-3.5$ & 3.4 & $2-3$ & $3-4$ & $2-3$ & $2-4$ & $2-3$ & $3-4$ \\
\hline
\end{tabular}

n: number. 
toes covered with minute spinules and tipped with small discs, metatarsal Inner metatarsal tubercle curved inward, its length equal its breadth at base, digit no digits, digits with thickened outer border.

Dorsal sides of the specimens were mostly light gray to olive-green or light brown, black spots with irregular black spots were seen. Thighs on posterior side were dark and one or two yellow or white irregular longitudinal stripes were also observed, ventral side of the specimens were white, spotless or with dark speckling or reticulation were found, vocal sacs were light brown. Male (38-43 mm) was smaller than female $(50-62 \mathrm{~mm})$ in snout-vent length in present study Table 1.

Water bodies were noted with highest number of frogs captured $(n=26)$ followed by cultivated land $(n=5)$ while least numbers were have been caught in un-cultivated land and human habitations ( $\mathrm{n}=1$ each) Table 2 .

Most specimens were sighted near water bodies (Table 2). The specimens were photographed at the same place for ensuring their morphological characteristics (Figure 2)During surveying the amphibian fauna of Malakand region, the authors collected thirty three specimens of Euphlyctis cyanophlyctis at 555 to $835 \mathrm{~m}$ elevation in the vicinity of Lower Dir district (Table 3 ). The stations were Talash ( $34^{\circ} 44^{\prime} 27^{\prime \prime}$ North, $71^{\circ} 52^{\prime} 38^{\prime \prime}$ East; 835 asl) on 10 June and 27 July, 2018; Ouch (720186, 347305; $693 \mathrm{~m}$ asl) $25^{\text {th }}$ of August and $7^{\text {th }}$ of September 2016, Timergara $(718423,348278 ; 823 \mathrm{~m}$ asl $) 28^{\text {th }}$ April and $10^{\text {th }}$ of May 2018, Ramorah at Chakdara (718423long 348278 alt; $693 \mathrm{~m}$ asl) $4^{\text {th }}$ May (Table 3). These stations are about $284 \mathrm{~km}$ away from Islamabad, capital of the country.

\section{Discussion}

Frog and toads are the most encountered anuran fauna in almost all the habitats in Malakand region, Pakistan. The great Mogul Emperor Babur (1526-1530) noted the peculiar skittering habit of Euphlyctis cyanophlyctis on water surface of a pond, and for the first time recorded it in his autobiography Babur-Nama (Beveridge, 1979;
Khan and Tasnim, 1987). Frog's crocking is the most familiar natural sound in the valley and is specially referred to in local folk songs and culture.

It shows changing seasons and indicates presence of water from a sound distance. It is a scientific fact that amphibians have an important biological role in riparian ecosystem as exist in Pakistan.

Euphlyctis cyanophlyctis is commonly known as skittering frog but local people called it "Tapakta Maindak" due to its particular type of jerky movement on the surface of water. This frog uses forest, shrub-land and wetland for living. Euphlyctis cyanophlyctis is the most common frog of Malakand region of Pakistan which is commonly observed in stagnant water bodies of the region.

The genus Euphlyctis consists of six species of which Euphlyctis cyanophlyctis (Schneider, 1799) is one of the most widespread species in southern Asia. This frog is one of the most general aquatic frog and regarded as weed species in frogs of Asia. This frog has wide range of distribution reported from Thailand to Nepal, throughout India, Sri Lanka and almost throughout Pakistan below $1800 \mathrm{~m}$ (Khan, 1997, 1999). Its several races have been described from Pakistan. In present survey specimens of this frog have been collected from all the habitat studies mostly in water bodies and from all the sites of the study region at different elevation. This species has been reported from different habitats in district Kasur, Punjab, Pakistan by Ali et al. (2016).

The present study demonstrates thirty three specimens (rural=18 and urban=15) in the study area including 15 male and 18 females. While after surveying the literature it is found that no published record is available in Lower Dir, Malakand region, Pakistan, therefore the present study was designed to document the presence of this species in rural and urban settlements of Malakand region, Pakistan. Khan and Khan (1997) analyzed and documented the snout vent length of the specimens to be between $40-47 \mathrm{~mm}$ for male and $45-62 \mathrm{~mm}$ for female during their study, whereas morphological characteristics of E.cyanophlyctis of the current study reveal specimens with lengths from 38-43 $\mathrm{mm}$ for male and $50-62 \mathrm{~mm}$ for female.

Table 2. Details of E.cynophlyctis captured from different habitat types in the study area.

\begin{tabular}{|c|c|c|c|c|c|}
\hline \multirow[b]{2}{*}{ Factors } & \multicolumn{4}{|c|}{ Specimens captured from } & \multirow{2}{*}{$\begin{array}{l}\text { Total specimens } \\
\text { captured }(n=33)\end{array}$} \\
\hline & $\begin{array}{l}\text { cultivated land } \\
\qquad(n=5)\end{array}$ & $\begin{array}{l}\text { un-cultivated } \\
\text { land }(n=1)\end{array}$ & $\begin{array}{c}\text { human } \\
\text { habitations }(n=1)\end{array}$ & $\begin{array}{c}\text { water bodies } \\
(\mathbf{n}=\mathbf{2 6})\end{array}$ & \\
\hline \multicolumn{6}{|l|}{ Areas } \\
\hline Urban & 2 & 0 & 0 & 16 & 18 \\
\hline Rural & 3 & 1 & 1 & 10 & 15 \\
\hline \multicolumn{6}{|l|}{ Sex } \\
\hline Male & 3 & 1 & 1 & 10 & 15 \\
\hline Female & 2 & 0 & 0 & 16 & 18 \\
\hline \multicolumn{6}{|l|}{ Age } \\
\hline Adult & 4 & 1 & 1 & 21 & 27 \\
\hline Juvenile & 1 & 0 & 0 & 5 & 6 \\
\hline
\end{tabular}

n: number. 


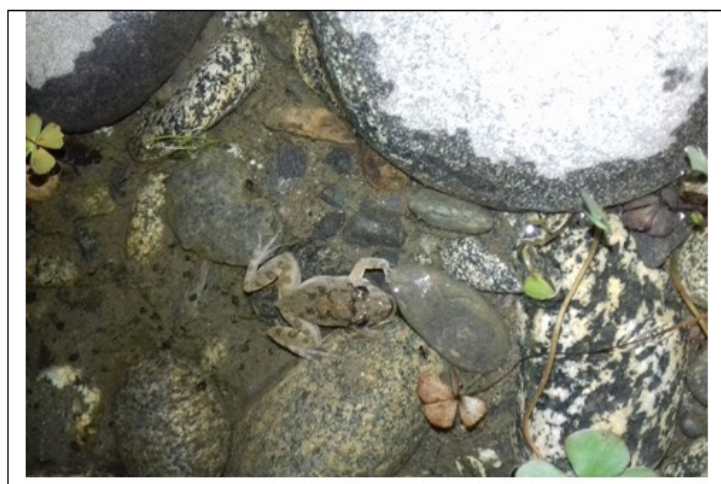

A. Young specimen
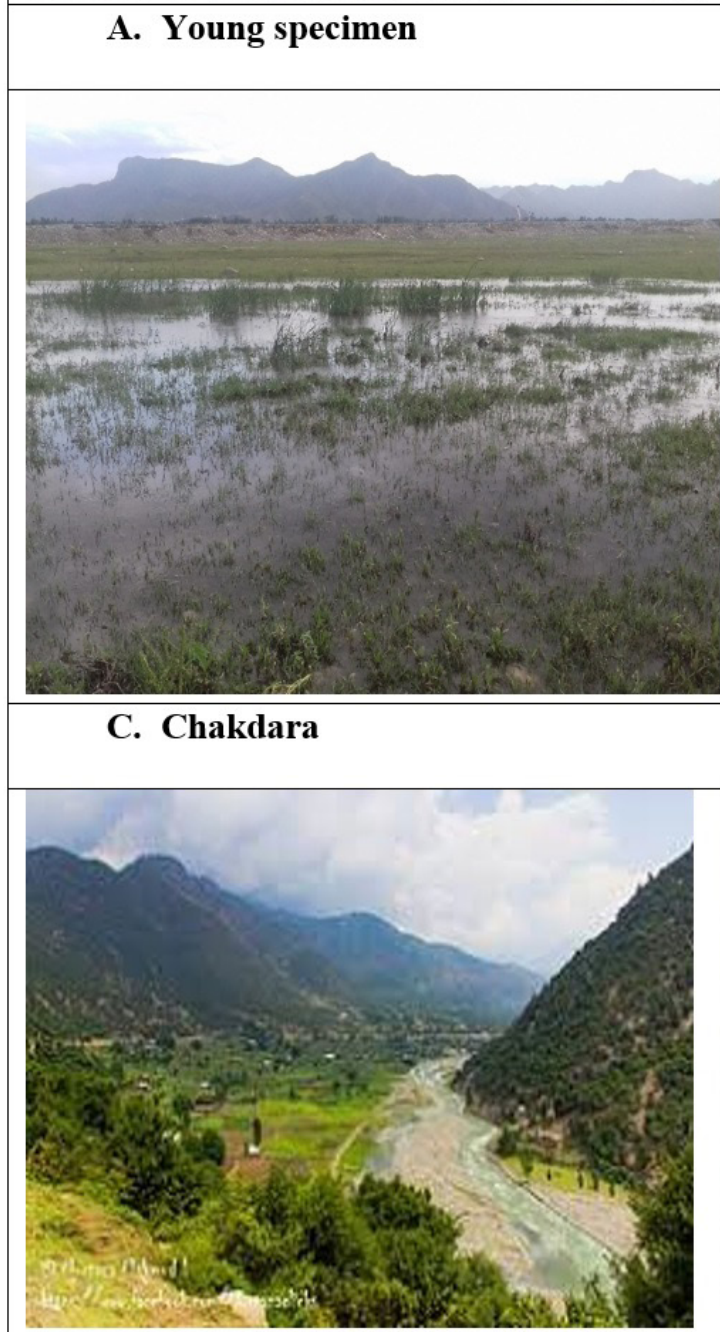

E. Talash

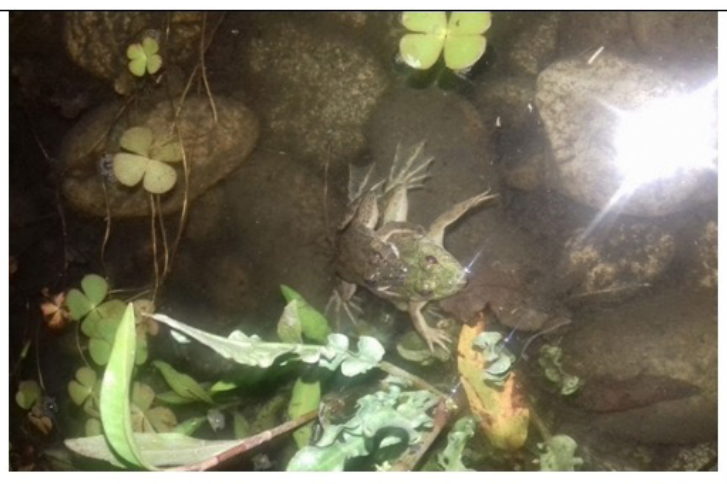

B. Specimens in mating

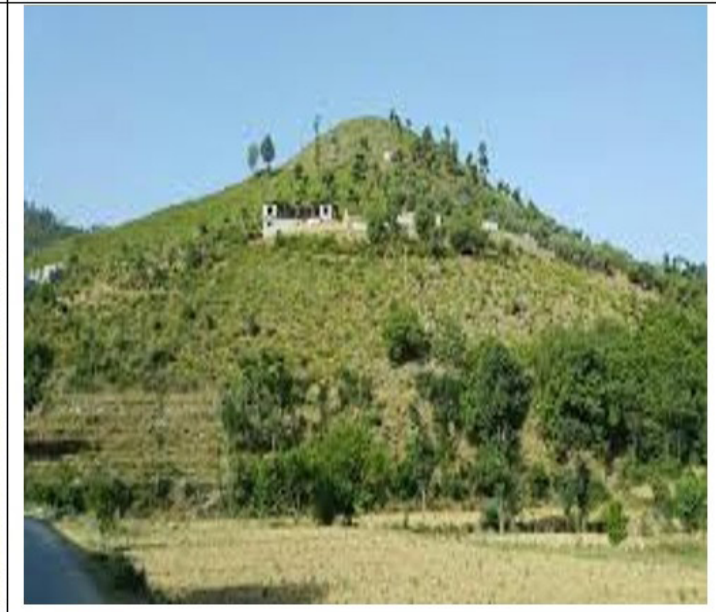

D. Timergara

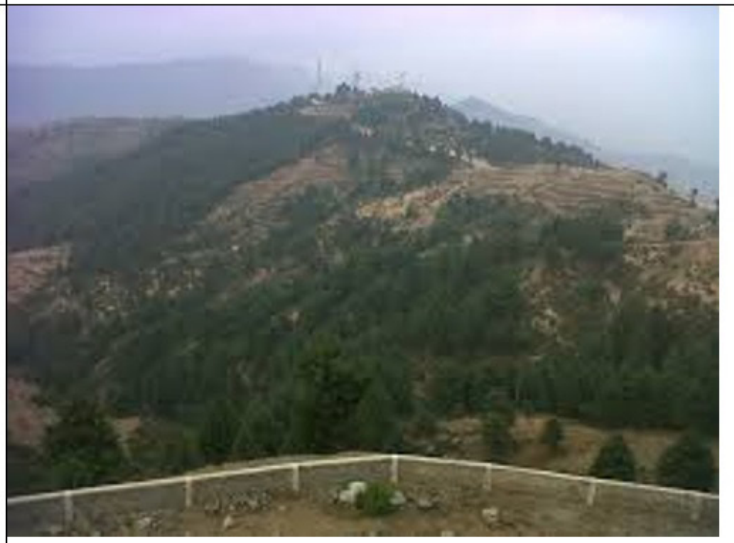

F. Ouch

Figure 2. (A \& B): frog specimens (C-F): sites of collection of the specimens Euphlyctis cyanophylictis in Lower Dir, Pakistan.

The water pollutants added by man, drainage system to water reservoirs, dryness of the ponds and puddles where this species breeds and presence of the natural predators in the form of snakes and birds, parasitic and fungal infection are common threat factors affect the population of this frog species in its habitat.
As amphibians are ignorant vertebrates perceived by the local people, awareness among the people about the importance is needed. The government authorities and scientists of the nature conservation should focus on the studies for the safeguard of this most innocent part of ecosystem. 
Table 3. Geographical coordinates of the study sites.

\begin{tabular}{|c|c|c|c|}
\hline site & Longitude ${ }^{\circ} \mathbf{E}$ & Latitude $^{\circ} \mathrm{N}$ & Elevation (average) $\mathrm{m}$ \\
\hline Chakdara & $72.0290^{\circ}$ & $34.6666^{\circ}$ & 693 \\
\hline Ouch & $72.0186^{\circ}$ & $34.7305^{\circ}$ & 555 \\
\hline Talash & $71.8720^{\circ}$ & $34.7415^{\circ}$ & 835 \\
\hline Timergara & $71.8423^{\circ}$ & $34.8278^{\circ}$ & 823 \\
\hline
\end{tabular}

\section{Acknowledgements}

We are thankful to Prof. Dr. Muhammad Sharif Khan, Herpetological Laboratory Rabwah, Pakistan for identification of the specimens and encouraging the publication of these observations.

\section{References}

ALI, W., JAVID, A., HUSSAIN, S. M., AZMAT, H. and JABEEN, G., 2016. The amphibians and reptiles collected from different habitat types in District Kasur, Punjab, Pakistan. Pakistan Journal of Zoology, vol. 48, no. 4, pp. 1201-1204.

ANDERSON, S.C., 1963. Amphibians and reptiles from Iran. Proceedings of the California Academy of Sciences, vol. 31, no. 4, pp. 417-498.

BALUCH, M. and KAMI, H.G., 1995. Amphibians of Iran. 2nd ed. Tehran, Iran: Tehran University Press.

BAUER, A.M., 1998. South Asian herpetological specimens of historical note in the Zoological Museum, Berlin. Hamadryad, vol. 23, pp. 133-149.

BEVERIDGE, A.S., 1979. Babur-Nama. Lahore: Sangemeel Publication.

BOULENGER, G.A., 1920. A monograph of the South Asian, Papuan, Melanesian and Australian frogs of the genus Rana. Records of the Indian Museum, vol. 20, pp. 1-226.

CHOWDHURY, M.A.W., RAHMAN, M.M. and KHAN, M.A.G., 2016. Influence of habitat parameters on common skipper frog(Euphlyctis cyanophlyctis) in Chittagong. Bangladesh Journal of Zoology, vol. 44, no. 1, pp. 133-146. http://dx.doi.org/10.3329/bjz.v44i1.30183.

DUBOIS, A., 1975. Un nouveau sous-genre (Paa) et Trois nouvelles espèces du genere Rana. Remarques sur la phylogenie des Ranidés (Amphibiens, Anoures). Bulletin du Muséum National D'Historoire Naturelle, vol. 3, no. 324, pp. 1093-1115.Zoologie 231.

FROST, D.R., 2013 [viewed 9 January 2013]. Amphibian Species of the World: an Online Reference. Version 5.6. New York:
American Museum of Natural History. Electronic database. Available from: http:// research. amnh. org/ herpetology/ amphibia/index.html

KHAN, M. S. and TASNIM, R., 1987. A field guide to the identification of herps of Pakistan. Part I, Amphibia. Pakistan: Biological Society of Pakistan. Monograph, no. 14, pp. 1-28.

KHAN, M.S. and KHAN, M.R.Z., 1997. A new skink from the Thal Desert of Pakistan. Asiatic Herpetological Research, vol. 7, pp. 61-67. http://dx.doi.org/10.5962/bhl.part.18856.

KHAN, M.S., 1997. A new subspecies of common skirting frog Euphlytictis cyanophlytis Schneider, 1799 from Balochistan Pakistan. Pakistan Journal of Zoology, vol. 29, no. 2, pp. 107-112.

KHAN, M.S., 1999. Herpetology of habitat types of Pakistan. Pakistan Journal of Zoology, vol. 31, pp. 275-289.

KHAN, M.S., 2004. Annotated checklist of amphibians and reptiles of Pakistan. Asiatic Herpetological Research, vol. 10, pp. 191-20.

KHAN, M.S., 2006. Amphibians and reptiles of Pakistan. Malabar, Florida: Krieger Publishing Company.

KHAN, M.S., 2010. Checklist of Amphibians of Pakistan. Pakistan Journal of Wildlife, vol. 1, no. 2, pp. 37-42.

KHAN, M.S., 2017. Herpetology of Pakistan: Part-1 (Fros E Toads). Bowling Green: Herpetological Laboratory, pp. 1-65.

KHAN, W., KHAN, J., RAHMAN, A., ULLAH, H., SALIM, M., IQBAL, M., KHAN, I., SALMAN, M. and MUNIR, B., 2018. Albendazole in the treatment of Hymenolepiasis in school children. Pakistan Journal of Pharmaceutical Sciences, vol. 31, no. 1, (suppl.), pp. 305-309. PMid:29386158.

NIKOLSKII, A.M., 1899. Reptiles, fishes, and Amphibia of the second expedition of N. A. Zarudni to Persia in 1898. Annals Museum of Zoological'Academy Impérial Science, vol. 4, no. 172-178, pp. 375-417. 